\title{
Huipiles, Maya Women's Weaving: A Dance with Time, a Salute to Place, Fabric of the Artist's Life
}

\section{Julia Kellman}

Human life is a tangle of influences, relationships, activities, beliefs and desires. The specifics shift from place to place but the framework of these needs and possibilities, dictated by biological and psychological concerns, is recognizable through time and from one place to another. Thus art objects as well are able to move from world to world due to their cross cultural appeal which is rooted in similar interests in craftsmanship, form, composition, color, and materials. These same categories appear over and over, affected by cultural dictates, environment, and personal esthetic, it is true, but nonetheless recognizable as the underlying structure of each artist's work. Therefore, it is possible to approach art from other cultures, armed at least with ques:ions either visually or vocally opposed, that will allow entry into an esthetic or art form seemingly unfamiliar at first glance and to the lives of other people separated from us in time and space.

Maya weaving, enchanting in its bright colors, rich patterns, and complex designs is immediately arresting, the way a colorful bird catches the eye in a dark background of green trees. When these fabrics are approached more closely, their density of images and profusion of scintillating forms becomes enigmatic. We seem to be driven to enquire into meaning, historical and cultural context, purpose, and production.

Meaning itself has received great attention, with a variety of people addressing the specifics of figures and patterns in both the prehistoric past and in women's work today and their presumed translation into descriptive language, stories, and legends. Production too has intrigued researchers interested in the actual weaving of cloth itself and excellent examinations of the various methods employed in placing the threads in the loom and of the types of fabrics themselves have been done.

For me, however, the spell of Maya women's weaving, and especially huipiles, traditional blouses which indicate indigenous community affiliation throughout Guatemala, lies in the manner in which it fits into the whole of their lives, defining them in their own minds and within their community as Maya women, bracketing their daily activities, and continuing as a theme from childhood to old age. Within this definition, marking, and continuity the women's personal esthetic decisions are made, linking them to the actual physical stuff of their world and their neighbors and allowing them at the same time space for individual expression and expertise. In order to reach some understanding of fitting and refitting that takes place throughout a woman's life of these functions into the pattern of her very existence and the means by

Working Papers in Art Education 1989 - 1990 
which a weaver achieves her ends, I have interviewed, chatted, photographed, shared meals, spent the night, and ridden buses with women, listening to their worries and concerns, talking about family matters, and discussing the vast fund of information and ideas that they have about their work.

Three women in three Cakchiquel Maya-speaking communities, set in the context of their families, form the basis of my enquiries and serve as exemplars for those communities and for women weavers in the wider Maya world. Encompassed by their ages (fourteen to fifty-one), community characteristics (poor or wealthy, rural and isolated or populous and near large towns, prehispanic in origin or hispanic invention), diverse family economic, educational, and living arrangements, is a good cross-section of weaving women's lives.

Theresa Gomez, a farmer's wife, and her family live in San Antonio Aguas Calientes, a small wealthy indigenous community seven kilometers from Antigua, the first capitol of Guatemala in the department of Sacatepequez. Her husband raises the traditional crops of corn, beans, and squash in his steep hillside fields at some distance from their home in San Antonio; the fields are reached only after a lengthy bus ride. San Antonio itself was formed by the Spanish soon after the conquest in 1524 to consolidate a mixture of several of the twenty-three Maya languages and peoples and African slaves into a work force for the nearby capitol and its fincas or farms. In the intervening years it has become a thoroughly traditional Cakchiquel Maya pueblo, integrated in language and custom and known for the excellence of its weaving. Though Theresa is no longer able to create the most complex figures due to failing eyesight (she is fifty-one), she is an excellent artist, with a lifetime of experience and a clear sense of weaving's place in her life. She is proud of the pieces she has done in the past and pleased with the work of her four daughters who now complete what she can no longer see to accomplish, as well as weave to meet their own needs, personal and economic. The women in the Gomez family not only produce their own huipiles, they also weave for the local stalls that sell fabrics to tourists who often come by bus during the day to buy mementos and visit this indigenous community.

Marta Simon, her husband Arnulfo, a teacher, their four-year-old son Erik, and now, new baby Roberto as well, live in San Juan Comalapa, another wealthy Maya community and municipo center two hours, more or less, from Antigua by bus in the department of Chimaltenango. This too is part of the Cakchiquel speaking area and most people speak both this, their native language, and Spanish. Marta has completed secondary school in accounting but has chosen to remain at home to care for her children while they are young rather than find other employment. Though busy as an anthropological informant, seamstress, and illustrator, she finds time to do some weaving, creating huipiles of great beauty in both traditional and more current styles for her own use. Her sister, Elvira, who still lives with their 
parents nearby, is a full time weaver, producing lovely pieces for sale to wealthy women in the community who cannot weave or do not have time.

Petrona Mejia Chuta is a fourteen-year-old student at El Instituto Indigena Nuestra Senora del Soccoro in Antigua, the only secondary school especially for Maya women in the country. Her home community, San Jose Poaquil, is remote, requiring many bumpy hours on the bus and usually a four kilometer walk as well to reach her father's farm in the little aldea of Saquitacaj on the spine of a ridge overlooking Poaquil in the valley below in the northwestern corner of the department of Chimaltenango. Petrona and her family speak Cakchiquel and Spanish, except for four-year-old Rosa, who knows only the Maya language. She will begin to learn Spanish as well when she enters school at the age of five.

All the women in this family are weavers and Rosa will most likely begin to learn when she is six. Petrona works on her own huipiles when she is home from the boarding school. Her mother and grandmother are both excellent craftswomen as is her cousin Eulalia, who lives on the other side of the narrow dirt road with her family and weaves for other women in the community, when possible, to earn money. Petrona's nine-year-old sister Maria, is already a consummate artist, and has three huipiles to her credit, a major task for so young a girl and a source of great pride for her family.

Thus, within these three women's lives and the world of their families, it is possible to begin to grasp a sense of the way their work means for them and to come to an enlarged understanding of not only these Maya women's weaving but a further illumination of art itself and its essential cultural functions and enduring human value.

Petrona serves as a convenient focus here, for her family encompasses weavers from youth to old age (Maria, age nine, to the grandmother, Feliciana, sixty-eight, who is terminally ill with asthma and amoebas), full time employment for money to work limited only to school vacations to meet personal needs (Eulalia to Petrona), well educated and not (Petrona to Felipa or Feliciana). All are part, nonetheless, of a community at some remove from the tourist market and now the various changing local traditional milieus and all are serious about their work.

Petrona herself will be the guide in this undertaking, just as she was for long rough miles by bus, through thick fog, and tiny villages to her parents' home perched on the lip of a ridge. Through her it will be possible to come to some necessarily brief understanding of the complex, richly colored cotton huipiles which are the focus of a woman's weaving and which in turn define her as a Maya woman and as a member of her community.

Huipiles indicate the community in which they were woven by their colors, figures or symbols, spacing, and materials. They reflect a woman's age in their construction, marking childhood, mid-life, and old age in their 
choice of neckline and often figures and colors also, for from Martia's written motif, Dream of Love in Spanish, placed in the center of the breast area of her hupil in progress and flanked by a profusion of flowers, to her grandmother's controlled and orderly use of slender registers and small precise figures, time, circumstance, and style are displayed and clarified. Huipiles exhibit women's expertise, inventiveness, and artistic abilities and each woman who is able to do so (there was no doubt of this in the past) weaves her masterpiece to wear for her wedding, confirming her skills in the domestic sphere and announcing her desirability as a wife, at the same time that she celebrates and enlivens this important occasion. These garments thus indicate their intended function, separating daily activities from solemn events in the varying nature of their colors, patterns, materials, and symbols. Life is bounded, defined, and enriched for Petrona and other Maya women by the simply constructed, elaborately woven garments and status at home and in the community as a whole is increased by skillful craftsmanship and a keen eye. Huipiles are one of the clearest outward links with the indigenous heritage and they tie a woman with their glowing threads to the multi-colored, age old world of home and community, serving to connect and fix her both in time and place.

Family pride and satisfaction in this area of women's work is obvious. Maria's precocious attainments are a source of admiration and comments by the other members of her family. Even her father, a quiet and somewhat aloof man, remarks on it. The weaving of Felipa and Feliciana is exhibited with delight and satisfaction by Petrona and Eulalia and they hold it up to themselves carefully so that it is possible to get the full effect. Little Rosa wears and models Maria's first two creations with verve and enthusiasm. Eulalia points out Petrona's white daily huipil with lavender, green, yellow, and blue figures, topped at the shoulders with a traditional Poaquil thin, orange stripe or creya, running the width of the garment. Petrona encourages me to buy a brown conservative huipil from Eulalia and offers to have Francisco sew it for me. We are awash in colors and pleasure in the fading light.

"Nothing ever begins," I think, as we talk in the long slanting setting sun, rising mist, and cold of their high ridge home. "There is no first moment; no single word or place from which this or any other story springs" (Barker, 1987, p. 4). for the narratives of these women tumble out together in a great shifting pattern of information which is set in the context of the complexities of their lives. One answers for another. They discuss and reach consensus. The smell of wood smoke fills the air. Children play. They interrupt. The young women speak for those who are not present. At various times Maria, Petrona, or Eulalia respond. I can hear Feliciana at the same time coughing in the bedroom and the soft pat-pat of Felipa's hands as she makes tortillas in the nearby kitchen. Huipiles are piled on the table. Looms lie in rolls with pieces in progress. The light fades.

I ask questions, trying to establish a sense of how weaving fits into these women's lives. We begin, therefore, at the beginning, when they learned and who was their teacher. Eulalia began at twelve; Petrona started at eight;

Working Papers in Art Education 1989 - 1990 
Maria at six. All three learned from their mothers and all are the children of farmers on this remote slice of land.

There are heaps of special huipiles, daily huipiles, works in progress on the rough board table. Next to it Maria hangs her loom to demonstrate her expertise. She weaves with abandon, her lip caught in her teeth as she concentrates on the pattern before her, taking care to show the counting of threads, the use of the brocading needle, the work of the wide wooden batten. Out of this weaving, answering, wearing, and showing a sense of the personal value of their work begins to grow, illustrating in the clearest way possible the centrality of this complex art to their lives. Within the specifics of community preferred characteristics, like dancers within the structure of a specific production,.they improvise, choose, perfect, experiment, and satisfy their artistic and esthetic needs. They weigh weaving choices on a carefully balanced scale of past and present, communal and personal, necessity and invention to create the garments in which they live their lives and which help to define them as traditional Maya women in their community and the wider world.

Within this profusion and confusion of fabrics and meanings expressed in the abstractions of form, color, space, and rhythm and addressed only in the half phrases of unarticulated musings, lies the explanation for this outpouring of beauty and its structure which enlivens the monochromatic greens, tans, and misty blues of the Highlands and punctuates these women's lives. It is not the repetition of images conjured long ago, the expression of obscure ritual activity, or a task assigned by the Spanish as a means of identification, it is the elegant implexed creation of the artist weaver, expressing her links to home, community, and history and growing out of her own being. It is her story. It has its beginning in the light in her eye, the pulse of her blood, her inner most self of personal meaning and need. It is the woman's dance with time, set carefully within the score written by the community it is true, but then no artist leaps free of her or his universe and its constraints. Weaving is a Maya woman's salute to place in its widest sense. Within the physicality of the huipil is the evidence of its creator's life and the enduring nature of art as a continuous and recognizable thread in human existence.

\section{Reference}

Barker, C. (1987). Weaveworld. New York: Simon and Schuster. 